\title{
Title: Keep It Up! 3.0: Study Protocol for a Type III Hybrid Implementation-Effectiveness Cluster- Randomized Trial
}

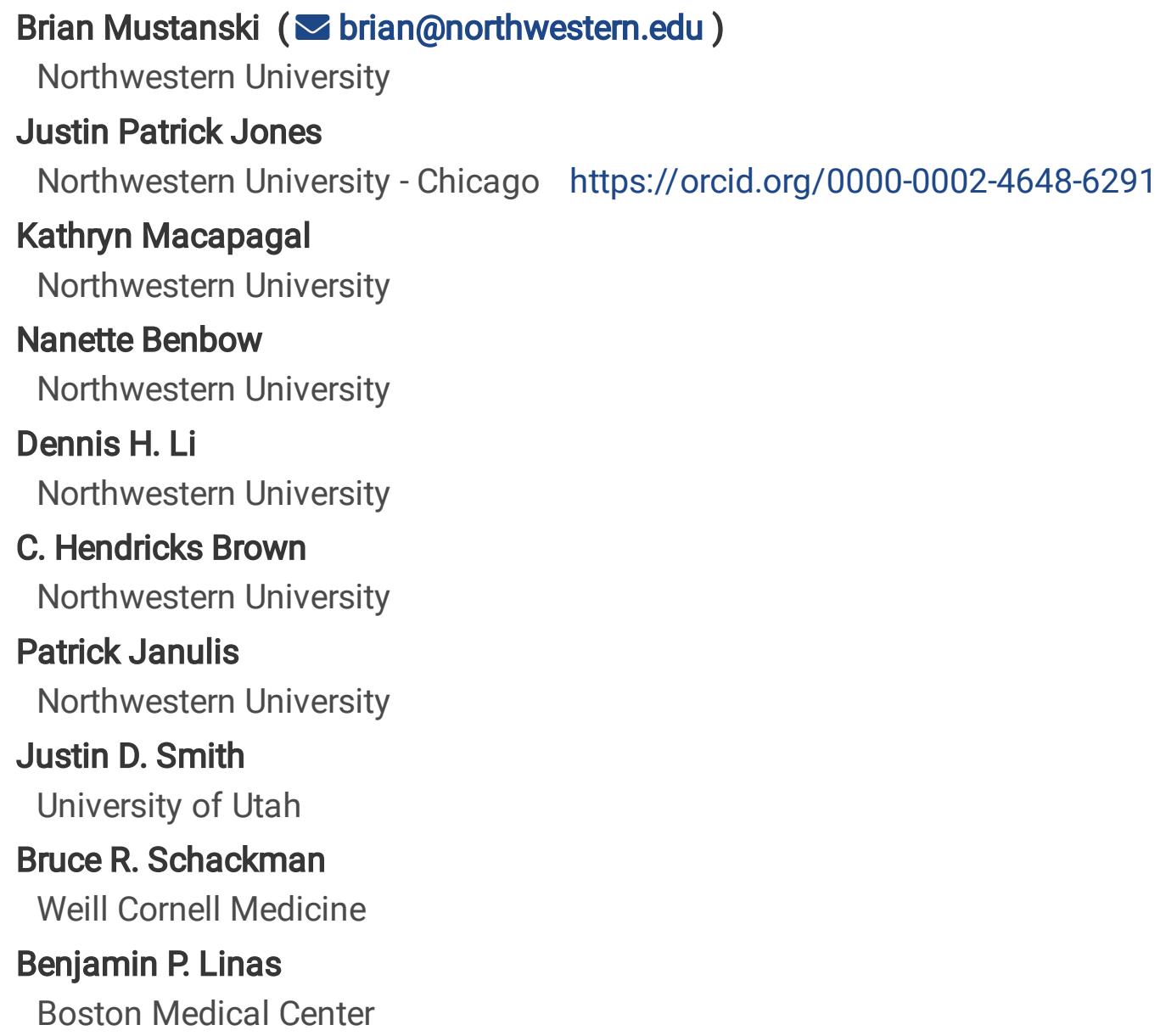




\section{Study protocol}

Keywords: HIV, eHealth, Young Men Who Have Sex With Men, Cluster Randomized Trial, Study Protocol, Type III Hybrid Implementation-Effectiveness, Community-Based Organization, Direct to Consumer

Posted Date: November 13th, 2020

DOI: https://doi.org/10.21203/rs.3.rs-104488/v1

License: (9) (1) This work is licensed under a Creative Commons Attribution 4.0 International License. Read Full License 


\section{Abstract}

Background

Young men who have sex with men are disproportionately impacted by the HIV epidemic in the United States. Few rigorously tested HIV prevention interventions have been developed for young men who have sex with men; previous interventions have primarily focused on in-person programming, with high variability in fidelity. With nearly all young men who have sex with men going online daily, eHealth approaches to prevention may successfully bridge research and practice. Keep It Up! is an eHealth HIV Prevention program for young men who have sex with men. Previous research has demonstrated its effectiveness in reducing sexually transmitted infections and condomless anal sex and efficiency in delivering HIV prevention education. Aim 1 is to compare two strategies for implementing KIU-implementation in community-based organizations and a centralized direct-to-consumer recruitment arm. Aim 2 is to examine adoption characteristics which explain variability in implementation success. Our exploratory aim will develop recommendations and materials for sustainment of KIU after completion of the trial.

Methods

This is a Type III Hybrid Effectiveness-Implementation cluster randomized trial. Using estimates of young men who have sex with men per county in the United States, we identified 113 counties for our sample frame. Using an iterative process, we selected 66 counties to randomize 2:1 to our two strategies in Aim 1. The REAIM model for implementation science will be used to drive our outcome measurements in reach, effectiveness, implementation variability, and cost. Outcome measures will be collected from communitybased organization staff participants, young men who have sex with men participants, and the technology provider. Our second aim will use mixed-methods research mapped onto the domains of the consolidated framework for implementation research.

\section{Discussion}

The trial has launched and is ongoing. This study is among the first to use a cluster randomized trial design in HIV implementation science. In comparing the community-based organization and direct to consumer models for recruitment and ongoing participant engagement, we are examining two strategies which have shown effectiveness in delivering health and technology interventions in the past, but with little base knowledge on their comparative advantages and disadvantages in implementation. The results of the trial will further understanding of the implementation of eHealth prevention interventions.

Trial Registration

NCT03896776, clinicaltrials.gov, 1 April 2019

\section{Contributions To The Literature}

- Our trial is among the first to study the implementation of an eHealth HIV prevention intervention. 
- Comparing two competing implementation strategies will contribute to knowledge about scaling up future eHealth interventions.

- Our research is among the first to use a cluster-randomized trial for HIV prevention science.

- Identifying clusters for randomization based on the local density of the target population is innovative.

\section{Background}

\section{YMSM, HIV, and STIs}

Young men who have sex with men (YMSM), ages 18-29, account for nearly $70 \%$ of all new HIV diagnoses among adolescents and young adults in the United States,(1) with HIV prevalence estimated at $13.6 \%$ in 18 24 year-olds and $18.5 \%$ in 25-29 year-olds. (2) HIV infections among YMSM are almost entirely transmitted via unprotected sex,(3-6) defined here as sex with neither Pre-Exposure Prophylaxis (PrEP) nor condoms. Sexually Transmitted Infection (STI) prevalence is also high among YMSM,(7-9) and STIs play an important role in increasing HIV transmission.(10-12) In fact, the Centers for Disease Control and Prevention (CDC) estimates a rectal STI causes a threefold increase in the per-act risk of HIV transmission during receptive anal sex.(13)

\section{Bridging the Research-Practice Divide}

Despite increased HIV risk, few interventions in the CDC Compendium of Evidence-Based Interventions (EBIs) and Best Practices for HIV Prevention Programs(6) are focused on YMSM.(14) The current arsenal of behavioral EBIs primarily includes face-to-face individual and small-group programs,(6) and their reach has been limited by economic and structural barriers to implementation.(15-20) EBIs have typically been delivered through practice settings such as health departments and community-based organizations (CBO), (21-23) and evidence suggests interventions are not always implemented with fidelity, $(15,16,24)$ which can produce a "voltage drop" in effectiveness.(25)

eHealth approaches represent a critical modality for engaging YMSM and delivering intervention content while overcoming barriers to access (e.g., geography $(26,27)$ ) and circumventing delivery challenges (e.g., fidelity(28)). Evidence from systematic reviews and meta-analyses indicate that eHealth programs have significant effects on HIV risk and protective behaviors comparable to in-person EBIs.(14, 29-31) Additionally, eHealth has been shown to improve youth access to healthcare services(32) and rates of HIV testing.(33)

\section{The Keep It Up! Intervention}

Keep It Up! (KIU) is a web-based, multimedia HIV prevention intervention developed with and for YMSM. Development and efficacy testing of KIU has been extensively described elsewhere.(34-38) In brief, KIU comprises seven modules completed across three sessions with mandatory 8-hour breaks between sessions. Additional content is provided in two booster sessions three and six months after the main intervention. Table 1-Content of the KIU Intervention provides an overview of subject matter covered within each module of the intervention as well as depicts the structured breaks between modules. 
Table 1

Content of KIU Intervention

\begin{tabular}{|c|c|c|}
\hline Episode & $\begin{array}{l}\text { Module } \\
\text { (Have Fun, } \\
\text { Stay Safe...) }\end{array}$ & Main Content \\
\hline \multirow[t]{3}{*}{1} & $\begin{array}{l}\text { In Your } \\
\text { Community }\end{array}$ & $\begin{array}{l}\text { Candid interviews with young gay and bisexual men about their communities, } \\
\text { family, sex, and relationships that situate these relationships as important } \\
\text { aspects of health. Similar interviews on various topics appear throughout the } \\
\text { program. }\end{array}$ \\
\hline & $\begin{array}{l}\text { Hooking Up } \\
\text { Online }\end{array}$ & $\begin{array}{l}\text { Three comic book vignettes about meeting men online for sex that focus on } \\
\text { identifying factors that may lead to increased HIV risk, such as mood and } \\
\text { substance use, as well as preparatory strategies to reduce those risks. }\end{array}$ \\
\hline & With Friends & $\begin{array}{l}\text { The first chapter of a scripted soap opera that highlights the risks of making } \\
\text { assumptions around HIV status and monogamy and promotes positive } \\
\text { norms around getting regular HIV testing and utilizing prevention strategies. } \\
\text { Remaining chapters appear throughout subsequent modules. }\end{array}$ \\
\hline
\end{tabular}

8-hour break

$2 \quad$ In Bars and

An interactive game that addresses the consequences of excessive alcohol Clubs consumption and drug use, as well as decisional balance around condom use.

On Dates

An animated story that explores how power dynamics in a dating relationship can affect sexual risk taking. Interactive risk calculators that demonstrate differing levels of HIV and STI risk based on various sexual behaviors.

8-hour break

$3 \quad$ In

Relationships

An interactive animated story and supporting videos that model using good communication skills in relationships to help meet one's sexual, emotional, and health needs.

In the Future

A goal-setting activity that helps participants identify ways to meet their sexual, emotional, and health needs and troubleshoot obstacles to achieving those goals.

3-month break
$4 \quad$ Knowing
Your Status
New videos and activities that focus on the importance of regular HIV testing in combination with prevention strategies like condoms and PrEP while adding additional layers of nuance, such as sexual pleasure and preventing condom use errors. There is also a check-in on participants' goals.

3-month break

$5 \quad$ In Love

In addition to checking in on participants' goals, new videos demonstrate when and how to discuss stopping condom use with a partner in a long-term relationship, as well as how to restart condoms after stopping.

KIU has been previously studied in several contexts. A pilot trial among 102 YMSM, ages 18-24, found a significant decrease in condomless anal sex (CAS) compared to a knowledge-based control.(36) A service implementation at a Chicago $\mathrm{CBO}$ showed significant pre-post reductions in condom errors, total number of male sex partners, and CAS among 579 men who have sex with men (MSM), ages 15-24.(34) A multi-city 
randomized clinical trial with 901 YMSM, ages 18-29, demonstrated a significant $40 \%$ decrease in STI incidence as well as a significant decrease in self-reported CAS. $(37,38)$ Intervention acceptability was high across all three studies, and KIU was subsequently designated a best-evidence HIV prevention intervention by the CDC.(39) KIU is one of the first eHealth HIV interventions with this level of evidence, making it the ideal intervention to study how to scale up.

\section{AIMS}

In this manuscript we describe the design of the KIU 3.0 trial, which has the following specific aims:

Aim 1: Compare two implementation strategies using a cluster-randomized trial (CRT). For Strategy 1, CBOs applied for funding to deliver KIU as a service. Strategy 2 is a direct-to-consumer (DTC) model wherein research staff at Northwestern University will recruit participants nationally through online advertising campaigns and manage their engagement.

Aim 2: Examine adoption characteristics that explain variability in implementation outcomes. We will seek to explain variability in implementation success across counties by conducting mixed-methods research $(40,41)$ on the domains from the consolidated framework for implementation research (CFIR).(42) Data on CFIR characteristics will be collected through administrative data, surveys, and teleconference interviews with key stakeholders.

Exploratory Aim. In addition to our 2 specific aims, we will explore sustainment of KIU at the completion of the study. $\mathrm{CBO}$ s will be provided with materials to facilitate applying for external funding to continue to provide KIU after study completion, including an Impact Tool(43) to estimate local impact and costs. We will also examine factors that predict applying for funding and ongoing sustainment.(44) For Strategy 2, we will examine options for ongoing sustainment of the DTC model.

\section{Methods}

\section{Cluster-Randomized Trial}

Aim 1: Compare two implementation strategies using a CRT.

\section{Sample Frame - County Selection and Randomization}

For our sample frame, we selected counties with an estimated number of YMSM greater than 1,500(45) $(\mathrm{N}=$ 113 counties). Counties in which KIU has been studied previously were excluded. We randomized 66 counties 2:1 to the CBO and DTC strategies, respectively. Our team opted to randomize 2:1 :: CBO:DTC because we expected that some counties would not have any CBOs apply, or if they applied, some counties' applicant CBOs would not meet minimal requirements for implementing KIU. Further, we randomized 22 counties to receive the KIU DTC strategy because we expected no selection loss(46) from counties where we will advertise online directly to YMSM. KIU will be delivered in each county for two years. Figure 1: KIU! 3.0 Trial Design illustrates our primary design elements. Figure 2 is a CONSORT diagram of the flow of the trial; a CONSORT 
checklist was provided as an additional file in submitting this manuscript. See the section entitled County Selection Iterative Process in Additional File 1 - Supplemental Information for more details.

\section{Participant Inclusion Criteria and Recruitment}

YMSM are eligible for participation in the research components of KIU if they meet the following criteria: 1) test negative for HIV at the time of registration, 2) report that they are assigned male at birth, 3) identify their current gender identity as male or identify as non-binary, 4) are between the ages of 18-29 at registration, 5) report CAS with a male partner in the previous six months, and 6) are not on PrEP, have been on PrEP for less than six months, or report missing a PrEP dose in the previous six months.

Participants will be recruited into KIU using different strategies based on the arm of the study into which they are recruited. For the $\mathrm{CBO}$ arm, participants will be recruited at CBO sites after testing negative for HIV. CBO staff will explain KIU and register interested YMSM, who will receive an email with a link that will take them to the application. Once there, participants will complete a baseline survey where their eligibility for the KIU research surveys is verified. In the DTC arm, participants will be recruited primarily through social media, geospatial dating apps, and supplemental approaches (e.g. referrals and print ads). Participants will click through or enter a URL to complete an initial screener for eligibility. When a participant meets all of the other indicators for eligibility, they will be sent an at-home HIV test kit to verify the HIV negative enrollment criterion as well as materials to self-administer swabs and a urine collection cup for oral, urethral, and rectal gonorrhea and chlamydia. See the section entitled DTC Recruitment in Additional File 1 - Supplemental Information for additional details on how remote recruitment, screening, and testing will take place in the DTC arm.

\section{Intervention Delivery}

KIU 3.0 is a custom mobile, tablet, and desktop responsive web-based application that is developed using multi-tenant architecture. KIU consists of five user roles with separate login pages and varying levels of access to the KIU application: Superusers, Project Directors, Coordinators, Recruiters, and YMSM participants. Superusers are comprised exclusively of Northwestern University project staff who oversee the application's functionality. CBO Project Directors oversee coordinator and recruiter efforts, have access to participant data for intervention retention, and act as primary contacts with KIU project staff at Northwestern University. NonYMSM user role distinctions are most salient for the CBO arm as DTC project staff functionally have the same level of access as CBO Project Directors. Following completion of the baseline survey, YMSM participants must complete KIU content in sequence, though they are able to return to previously viewed material via a learning map. For more details on intervention delivery, including data collected by the application and the experience of YMSM, see the section entitled KIU Intervention Delivery in Additional File 1 - Supplemental Information.

\section{Implementation Strategies - Community-Based Organization Arm - RFP Process}

To select CBO recruitment sites, we wrote a request for proposals (RFP) modeled on various RFPs created by $\mathrm{CDC}$ and other funders of HIV prevention. Following, we developed an objective scoring rubric and trained objective reviewers to score 3-4 applications on nine criteria. Each application was scored by three distinct review panelists. Once scores were submitted, we averaged each application's scores and selected the highest 
scoring applicants for implementation. See the section entitled RFP Process in Additional File 1 Supplemental Information for more details.

\section{Implementation Strategies - Community-Based Organization - Training}

Northwestern project staff developed and disseminated online training to CBO implementers. Training modules covered topics ranging from using the implementer dashboard to recruitment strategies. Hosted on the KIU platform, the training includes seamless integration of KIU content. To ensure continuous improvement, Northwestern project staff offer ongoing technical assistance to meet emergent needs of the trial. See the section entitled Training in Additional File 1 - Supplemental Information for more details.

\section{Implementation Strategies - Direct to Consumer Arm - Incentives}

In the DTC arm, participants will receive a \$10 or \$25 pre-loaded virtual Visa gift card for completing the first three sessions of the intervention. Incentive amount is randomized by county in order to determine if a threshold amount must be met for incentives to be effective. DTC participants will also receive a discount code for an online store that sells adult toys and products. Participants will be entered into an e-raffle for various prizes donated by vendors as an incentive for completing the booster content at 3- and 6-months post-intervention. This strategy is based on those successfully used by CBO partners in previous KIU service implementations to keep their clients engaged.(34) Participants across both arms of the trial are entered into raffles for $\$ 200$ gift cards when they complete research surveys at baseline, 3, 6, and 12 months postintervention.

\section{Measures}

The RE-AIM model $(47,48)$ broadly guided our outcome measurement framework. Aim 1 will use quantitative data on Reach, Effectiveness, and Implementation, while Aim 2 will pull from mixed-methods data on Adoption and qualitative data to explore Maintenance and Sustainability. Outcomes will be measured across four domains: (1) reach to high risk YMSM; (2) effectiveness at reducing HIV risk among engaged YMSM;(47, $49,50)$ (3) implementation variability; $(51)$ and $(4)$ cost for delivery. $(52,53)$ See Table 2 : Reach to High Risk YMSM; Table 3: Effectiveness at Reducing HIV Risk among Engaged YMSM; Table 4: Variability in Implementation Success; and Table 5: Cost Elements for a list of outcomes measured by assessment time point. 
Table 2

Reach to High Risk YMSM

\begin{tabular}{|c|c|c|c|c|c|}
\hline \multirow[t]{2}{*}{ Level } & \multirow[t]{2}{*}{ Construct } & \multirow{2}{*}{$\begin{array}{l}\text { Measure/ } \\
\text { Operationalization }\end{array}$} & \multicolumn{3}{|c|}{ Measurement Schedule } \\
\hline & & & Screening & Baseline & Quarterly \\
\hline \multirow[t]{5}{*}{$\begin{array}{l}\text { YMSM } \\
\text { Participant }\end{array}$} & \multirow[t]{5}{*}{ Reach } & $\begin{array}{l}\text { Proportion of YMSM in county screened } \\
\text { for KIU }\end{array}$ & $x$ & & \\
\hline & & $\begin{array}{l}\text { Proportion of invited YMSM who begin } \\
\text { KIU }\end{array}$ & $X$ & $x$ & \\
\hline & & $\begin{array}{l}\text { Proportion of KIU Participants that are } \\
\text { Black or Latino }\end{array}$ & & $X$ & \\
\hline & & $\begin{array}{l}\text { Proportion of KIU Participants with an } \\
\text { STI at enrollment }\end{array}$ & & $x$ & \\
\hline & & $\begin{array}{l}\text { Proportion of KIU Participants who } \\
\text { engaged in unprotected sex (no condom } \\
\text { or PrEP) in prior } 6 \text { months }\end{array}$ & & $x$ & \\
\hline \multirow[t]{6}{*}{ CBO } & \multirow[t]{6}{*}{ Reach } & Total number of HIV tests conducted & & $\mathrm{X}$ & $X$ \\
\hline & & $\begin{array}{l}\text { Number of HIV tests conducted with } \\
\text { YMSM }\end{array}$ & & $x$ & $x$ \\
\hline & & $\begin{array}{l}\text { Number of YMSM who tested non- } \\
\text { reactive }\end{array}$ & & $x$ & $x$ \\
\hline & & Number of enrolled KIU Participants & & $\mathrm{X}$ & $X$ \\
\hline & & $\begin{array}{l}\text { Number of clients tested for Gonorrhea } \\
\text { and/or Chlamydia }\end{array}$ & & $x$ & $x$ \\
\hline & & $\begin{array}{l}\text { Number of Gonorrhea and/or Chlamydia } \\
\text { tests conducted with YMSM }\end{array}$ & & $x$ & $x$ \\
\hline
\end{tabular}


Table 3

Effectiveness at Reducing HIV Risk among Engaged YMSM

\begin{tabular}{|c|c|c|c|c|c|c|}
\hline \multirow{3}{*}{$\begin{array}{l}\text { Outcome } \\
\text { Type }\end{array}$} & \multirow[t]{3}{*}{ Construct } & \multirow{3}{*}{$\begin{array}{l}\text { Measure/ } \\
\text { Operationalization }\end{array}$} & \multicolumn{4}{|c|}{ Measurement Schedule } \\
\hline & & & \multirow[t]{2}{*}{ Baseline } & & & \\
\hline & & & & month & month & month \\
\hline \multirow[t]{4}{*}{ Primary } & \multirow[t]{3}{*}{$\begin{array}{l}\text { HIV Risk } \\
\text { Behavior }\end{array}$} & $\begin{array}{l}\text { Number of condomless male } \\
\text { assigned at birth (MAAB) sex } \\
\text { partners }\end{array}$ & $x$ & $X$ & $X$ & $x$ \\
\hline & & $\begin{array}{l}\text { Number of condomless MAAB sex } \\
\text { partners who are casual }\end{array}$ & $x$ & $x$ & $X$ & $x$ \\
\hline & & $\begin{array}{l}\text { Risk behavior associated with } \\
\text { most recent sexual encounter: } \\
\text { condoms, PrEP, substance use }\end{array}$ & $x$ & $X$ & $X$ & $x$ \\
\hline & $\begin{array}{l}\text { STI } \\
\text { Incidence }\end{array}$ & $\begin{array}{l}\text { Urethral and rectal Chlamydia and } \\
\text { Gonorrhea - Aptima Combo } 2 \\
\text { Assay on the Panther system(1) }\end{array}$ & $X$ & & & $x$ \\
\hline \multirow{2}{*}{$\begin{array}{l}\text { Secondary: } \\
\text { Prevention } \\
\text { Continuum }\end{array}$} & $\begin{array}{l}\text { HIV/STI } \\
\text { Testing }\end{array}$ & $\begin{array}{l}\text { Assessing past 3-month HIV and } \\
\text { STI testing history }\end{array}$ & $x$ & $x$ & $X$ & $x$ \\
\hline & $\begin{array}{l}\text { PrEP Use } \\
\& \\
\text { Adherence }\end{array}$ & $\begin{array}{l}\text { Current \& past 3-month PrEP use; } \\
\text { adherence }\end{array}$ & $x$ & $X$ & $X$ & $x$ \\
\hline \multirow[t]{2}{*}{$\begin{array}{l}\text { Secondary: } \\
\text { Substance } \\
\text { Use }\end{array}$} & $\begin{array}{l}\text { Alcohol } \\
\text { Problems }\end{array}$ & $\begin{array}{l}\text { AUDIT Alcohol Consumption } \\
\text { Questions (AUDIT-C)(2); Full } \\
\text { Alcohol Use Disorders } \\
\text { Identification Test (AUDIT) } \\
\text { branched to those scoring }>3(3)\end{array}$ & $X$ & $X$ & $X$ & $X$ \\
\hline & $\begin{array}{l}\text { Other } \\
\text { Drug Use }\end{array}$ & $\begin{array}{l}\text { Past 3-month use of marijuana } \\
\text { and illicit drugs }\end{array}$ & $x$ & $x$ & $X$ & $X$ \\
\hline \multicolumn{7}{|c|}{ 1. Incorporated G-P. Aptima Combo 2 Assay for Panther System Package Insert. San Diego, CA2016. } \\
\hline \multicolumn{7}{|c|}{$\begin{array}{l}\text { 2. Bush K, Kivlahan DR, McDonell MB, Fihn SD, Bradley KA. The AUDIT alcohol consumption questions } \\
\text { (AUDIT-C): an effective brief screening test for problem drinking. Ambulatory Care Quality Improvement } \\
\text { Project (ACQUIP). Alcohol Use Disorders Identification Test. Arch Intern Med. 1998;158(16):1789-95. }\end{array}$} \\
\hline \multicolumn{7}{|c|}{$\begin{array}{l}\text { 3. Saunders JB, Aasland OG, Babor TF, de la Fuente JR, Grant M. Development of the Alcohol Use } \\
\text { Disorders Identification Test (AUDIT): WHO collaborative project on early detection of persons with } \\
\text { harmful alcohol consumption-II. Addiction. 1993;88(6):791-804. }\end{array}$} \\
\hline
\end{tabular}


Table 4

Variability in Implementation Success

\begin{tabular}{|c|c|c|c|c|c|c|c|}
\hline \multirow[t]{3}{*}{ Level } & \multirow[t]{3}{*}{ Construct } & \multirow{3}{*}{$\begin{array}{l}\text { Measure/ } \\
\text { Operationalization }\end{array}$} & \multicolumn{5}{|c|}{ Measurement Schedule } \\
\hline & & & \multirow[t]{2}{*}{$\begin{array}{l}\text { Base- } \\
\text { line } \\
\text { (YMSM) } \\
\text { or Pre- } \\
\text { Launch } \\
\text { (CBO) }\end{array}$} & $\begin{array}{l}\text { 3- } \\
\text { month } \\
\text { (YMSM) } \\
\text { or }\end{array}$ & $\begin{array}{l}\text { 6- } \\
\text { month }\end{array}$ & $\begin{array}{l}12- \\
\text { month }\end{array}$ & $\begin{array}{l}\text { 24- } \\
\text { month }\end{array}$ \\
\hline & & & & $\begin{array}{l}\text { 4-month } \\
\text { (CBO) }\end{array}$ & & & \\
\hline \multirow[t]{4}{*}{$\begin{array}{l}\text { YMSM } \\
\text { Participant }\end{array}$} & Self-Efficacy & $\begin{array}{l}\text { Confidence in HIV } \\
\text { testing, condom } \\
\text { use, and ability to } \\
\text { get on PrEP }\end{array}$ & $\mathrm{x}$ & $x$ & $\mathrm{x}$ & $x$ & \\
\hline & $\begin{array}{l}\text { Resource } \\
\text { Access }\end{array}$ & $\begin{array}{l}\text { Access to HIV } \\
\text { testing, HIV } \\
\text { prevention } \\
\text { services, and } \\
\text { other sexual } \\
\text { health services }\end{array}$ & $x$ & $x$ & $\mathrm{x}$ & & \\
\hline & Stigma & $\begin{array}{l}\text { Sexual health care } \\
\text { avoidance due to } \\
\text { LGBTQ stigma }\end{array}$ & $x$ & & & & \\
\hline & Satisfaction & $\begin{array}{l}\text { Satisfaction with } \\
\text { DTC or CBO staff } \\
\text { and services }\end{array}$ & $x$ & $x$ & $x$ & & \\
\hline \multirow[t]{2}{*}{$\begin{array}{l}\text { Technology } \\
\text { Center }\end{array}$} & Engagement & $\begin{array}{l}\text { Mean number of } \\
\text { KIU modules } \\
\text { completed by } \\
\text { Participants }\end{array}$ & & & & & \\
\hline & & $\begin{array}{l}\text { System analytics; } \\
\text { Metrics of activity } \\
\text { within modules }\end{array}$ & & & & & \\
\hline \multirow[t]{5}{*}{ CBO } & Demographics & & $x$ & & & & \\
\hline & $\begin{array}{l}\text { Effectiveness } \\
\text { and } \\
\text { Satisfaction } \\
\text { with Training }\end{array}$ & $\begin{array}{l}\text { Effectiveness and } \\
\text { Satisfaction with } \\
\text { Training }\end{array}$ & $x$ & $x$ & & & \\
\hline & $\begin{array}{l}\text { Normalization } \\
\text { Process Theory }\end{array}$ & $\begin{array}{l}\text { NoMAD: } \\
\text { Normalization } \\
\text { Process(1) }\end{array}$ & $x$ & $x$ & & $x$ & $x$ \\
\hline & $\begin{array}{l}\text { Organizational } \\
\text { Readiness for } \\
\text { Change }\end{array}$ & $\begin{array}{l}\text { OCRBS: } \\
\text { Organizational } \\
\text { Change Recipient } \\
\text { Beliefs Scale(2) }\end{array}$ & $x$ & & & & \\
\hline & $\begin{array}{l}\text { Leadership } \\
\text { Engagement }\end{array}$ & $\begin{array}{l}\text { ILS: } \\
\text { Implementation }\end{array}$ & $x$ & $x$ & & $x$ & $x$ \\
\hline
\end{tabular}




\begin{tabular}{|c|c|c|c|c|c|c|}
\hline $\begin{array}{l}\text { Implementation } \\
\text { Climate }\end{array}$ & $\begin{array}{l}\text { ICS: } \\
\text { Implementation } \\
\text { Climate Scale(4) }\end{array}$ & $x$ & & & $x$ & $x$ \\
\hline $\begin{array}{l}\text { Readiness for } \\
\text { eHealth }\end{array}$ & $\begin{array}{l}\text { Readiness for } \\
\text { eHealth } \\
\text { (Developed from } \\
\text { cited sources)(5- } \\
7 \text { ) }\end{array}$ & $x$ & & & & \\
\hline Sustainability & $\begin{array}{l}\text { Program } \\
\text { Sustainability } \\
\text { Assessment } \\
\text { Tool(8) }\end{array}$ & & & & $x$ & $x$ \\
\hline Adaptation & $\begin{array}{l}\text { Items based on } \\
\text { the Frame } \\
\text { measure }(9)\end{array}$ & & & & $x$ & $x$ \\
\hline \multirow[t]{2}{*}{ CFIR domains } & $\begin{array}{l}\text { Administrative } \\
\text { Data }\end{array}$ & $x$ & $x$ & $x$ & $x$ & $x$ \\
\hline & $\begin{array}{l}\text { Qualitative } \\
\text { Interviews }\end{array}$ & $x$ & & & $x$ & \\
\hline
\end{tabular}

1. Finch TL, Girling, M., May, C.R., Mair, F.S., Murray, E., Treweek, S., Steen, I.N., McColl, E.M., Dickinson, C., Rapley, T.. Nomad: Implementation measure based on Normalization Process Theory. [Measurement instrument]. Retrieved from http://www.normalizationprocess.org. 2015 [

2. Armenakis AA BJ, Pitts JP, Walker HJ. Organizational Change Recipients Beliefs Scale: Development of an Assessmetn Instrument. The Journal of Applied Behavioral Science 2007;42:481-505.

3. Aarons GA EM, Torres EM, Finn NK, Roesch SC. Validation of the Implementation Leadership Scale (ILS) in substance use disorder treatment organizations. Journal of substance abuse treatment 2016;68:31- 5 .

4. Ehrhart MG, Aarons GA, Farahnak LR. Assessing the organizational context for EBP implementation: the development and validity testing of the Implementation Climate Scale (ICS). 2014;9:157.

5. Weichelt B. Health in Your Hand: Assessment of Clinicians' Readiness to Adopt Mhealth into Rural Patient Care. Theses and Dissertations2016.

6. Khatun F HA, Ray PK, Hanifi SMA, Bhuiya A, Liaw S-T. Determinants of readiness to adopt mHealth in a rural community of Bangladesh. International Journal of Medical Informatics. 2015;84(10):847 - 56.

7. Khatun F HA, Ray PK, Bhuiya A, Liaw S-T. Community Readiness for Adopting mHealth in Rural Bangladesh: A Qualitative Exploration. International Journal of Medical Informatics. 2016;93:49-56.

8. Luke DA CA, Robichaux CB, Elliott MB, Moreland-Russell S. The Program Sustainability Assessment Tool: A new instrument for public health programs. Preventing Chronic Disease. 2014;11.

9. Wiltsey Stirman S, Baumann AA, Miller CJ. The FRAME: an expanded framework for reporting adaptations and modifications to evidence-based interventions. Implement Sci. 2019;14(1):58. 
Table 5

Cost Elements

\begin{tabular}{|c|c|c|c|c|}
\hline Cost Type & Construct & Measures & Source & $\begin{array}{l}\text { Measurement } \\
\text { Schedule }\end{array}$ \\
\hline \multirow[t]{3}{*}{ Start-Up } & Recruitment & $\begin{array}{l}\text { Staff time, consultant and } \\
\text { other costs }\end{array}$ & $\begin{array}{l}\text { Staff activity logs; } \\
\text { study records and CBO } \\
\text { interviews/surveys }\end{array}$ & $\begin{array}{l}\text { Monthly for } \\
\text { start-up } \\
\text { period; one- } \\
\text { time }\end{array}$ \\
\hline & Initial Training & $\begin{array}{l}\text { Number and duration of } \\
\text { trainings }\end{array}$ & Study records & One-time \\
\hline & $\begin{array}{l}\text { Technology } \\
\text { development }\end{array}$ & $\begin{array}{l}\text { Staff time, content } \\
\text { development costs }\end{array}$ & Staff activity logs & $\begin{array}{l}\text { Monthly for } \\
\text { start-up } \\
\text { period; one- } \\
\text { time }\end{array}$ \\
\hline \multirow[t]{2}{*}{ Variable } & $\begin{array}{l}\text { Shipping and } \\
\text { processing HIV } \\
\text { and STI test kits }\end{array}$ & $\begin{array}{l}\text { Number of units shipped, } \\
\text { STI lab cost per test, staff } \\
\text { time per shipment }\end{array}$ & $\begin{array}{l}\text { Study records; staff } \\
\text { interviews }\end{array}$ & $\begin{array}{l}\text { Ongoing; one- } \\
\text { time }\end{array}$ \\
\hline & $\begin{array}{l}\text { Participant } \\
\text { contacts }\end{array}$ & $\begin{array}{l}\text { Number of Participant } \\
\text { contacts, staff time per } \\
\text { contact }\end{array}$ & $\begin{array}{l}\text { Participant contact } \\
\text { logs; staff interviews }\end{array}$ & $\begin{array}{l}\text { Ongoing; one- } \\
\text { time }\end{array}$ \\
\hline \multirow[t]{4}{*}{$\begin{array}{l}\text { Time- } \\
\text { Dependent }\end{array}$} & $\begin{array}{l}\text { Social Media } \\
\text { Advertisement }\end{array}$ & Total spending & Study records & Ongoing \\
\hline & $\begin{array}{l}\text { Booster Training } \\
\text { and Technical } \\
\text { Assistance }\end{array}$ & Staff time by arm & $\begin{array}{l}\text { CBO and DTC } \\
\text { Participant tracking } \\
\text { logs; staff activity logs }\end{array}$ & $\begin{array}{l}\text { Ongoing; } \\
\text { monthly }\end{array}$ \\
\hline & $\begin{array}{l}\text { Other staff } \\
\text { activities }\end{array}$ & Staff time by arm & $\begin{array}{l}\text { Staff activity logs; CBO } \\
\text { interviews/surveys }\end{array}$ & $\begin{array}{l}\text { Monthly; one- } \\
\text { time }\end{array}$ \\
\hline & $\begin{array}{l}\text { Space and } \\
\text { occupancy costs }\end{array}$ & Square feet & Staff interviews & One-time \\
\hline
\end{tabular}

\section{Data Analysis - Public Health Impact}

Our primary outcomes are public health impact $(\mathrm{PHI})$, defined as reach $\mathrm{X}$ effectiveness $(47,49,50)$, and cost per infection averted. $(54,55)$ For this trial, PHI will be assessed by $(1)$ reach into the county's YMSM community, weighted by HIV risk, and (2) effectiveness at reducing HIV risk.(47, 49, 50) By measuring individual-level change on these modifiable factors, our index of $\mathrm{PHI}$ will allow for heterogeneity in response to KIU across individuals, race and age groups, counties, and implementation condition. Effectiveness will be marked by the estimated change in that person's risk for HIV from baseline to follow-up surveys, determined by observed changes in target risk behavior: CAS, STIs, and adherent PrEP use, all of which have major impacts on HIV transmission in MSM.(56-58) We will base our modeling of HIV risk on published singleexposure probabilities and account for multiple exposures using binomial modeling.(59) Because these are individual-based measures, we will use two-level mixed-effect modeling.(60) Measuring cost is described below, and from these we will compute cost per infection averted, which is analogous to the measure used by 
CDC to decide which effective HIV prevention intervention would be supported as part of high impact prevention. $(54,55)$

We will follow established guidelines for collecting cost data and conducting economic evaluations and will conduct cost analyses for each arm from the perspective of the healthcare sector. $(52,53)$ We will follow a micro-costing approach, a technique in which all inputs consumed in an intervention are identified and quantified in detail and then converted into fiscal terms to produce a cost estimate.

\section{Data Analysis - Compare CBO and DTC Implementation Strategies}

We will employ Multivariable Generalized Linear Mixed Models (GLMM) for our analyses, as they account for nested individual observations within counties and are commonly used in CRTs. $(53,61)$ The multivariable aspect of the model will allow for the control of factors that are unbalanced between arms either because they were not accounted for in the randomization process or because they may have become unbalanced due to loss to follow-up. To account for potential selection bias in constructing an efficient (1 degree of freedom) adjustment for measured differences in county-level covariates, we will adjust for the linear combination forming the first canonical covariate that maximally distinguished the sites in the two arms. $(46,62)$ Similar to propensity score analysis, we will also formally include the model that predicts selection effects.(63) We will estimate standard errors using nonparametric bootstrapping techniques within the multivariable framework treating arm as a dichotomous indicator.(53) The differences between the intervention arms will be evaluated by examining the statistical significance of the level-2 (i.e., cluster level) dichotomous indicator for the intervention arms. We will estimate and compare the difference in predicted mean cost per participant between the arms, and will also use those estimates of mean cost to characterize the cost per HIV infection averted in each arm of the study.

For cost-effectiveness analysis, parameters obtained from bootstrapping will be used to estimate costeffectiveness acceptability curves which will indicate the probability that either intervention is a good value for different willingness-to-pay thresholds (i.e., incremental cost per infection avoided).(64) Finally, all analysis of outcomes will conform to best practices in analysis of randomized trials, including intention-totreat analysis and sensitivity analysis of missing data and multilevel multiple imputation in order to examine the potential effect of missing responses on the results.(65-67)

\section{Study Status}

The KIU trial commenced in October 2019. As of October 2020, the DTC arm has begun recruitment in all 22 of its counties. The $\mathrm{CBO}$ arm has launched 20 counties for recruitment; the remaining two sites will initiate their programs in fall 2020. The CBO arm has gathered both qualitative and quantitative baseline data on implementation from 20 CBOs. See the section entitled CBO and DTC Study Statuses in Additional File 1 Supplemental Information for additional details on study status for each arm.

\section{Discussion}

A large CRT is innovative in HIV research. There has been a recent increase in their use in public health and medicine,(68) but with a few important exceptions,(69-72) they have not seen significant application in HIV 
implementation science. Our design of systematically selecting counties with large YMSM populations and then randomizing them to an implementation strategy is innovative. Particularly innovative is our strategy to solicit RFPs from CBOs in eligible counties. This approach is pragmatic in that it matches the approach used by the $\mathrm{CDC}$ and health departments to distribute prevention funds to $\mathrm{CBO}$.

Our trial compares the implementation of two competing implementation strategies - CBO vs DTC. Both are viable strategies for eHealth intervention dissemination. The $\mathrm{CBO}$ model, with $\mathrm{CBO}$ s directly funded by the $\mathrm{CDC}$ or their local health department,(73) is the current backbone of implementing HIV prevention programs. The DTC model introduces a novel method of mitigating barriers to regular HIV/STI testing(74-78) by facilitating self-testing, which has been demonstrated to be accurate, acceptable, and feasible, especially among those who may not otherwise seek an HIV test.(79-85) While both the CBO and DTC arms are two viable implementation strategies, their relative advantages and disadvantages are unknown, and we do not know the circumstances where one is more valuable than the other. By evaluating both strategies head-tohead in this large trial, we will be able to discern their overall effectiveness and identify key moderating factors $(51,86)$ that could help boost and shape future dissemination and implementation of eHealth HIV prevention interventions $(87,88)$ and contribute to greater scalability, reach, and public health impact.

Our trial will contribute to implementation science, with a particular focus on eHealth. Effective implementation has been described as the greatest challenge to HIV prevention,(89) yet there has been insufficient research testing implementation strategies that will ensure effective interventions get to the right individuals at the right time in the right dose. $(15,16,20)$ While prior implementation science has compared capacity-building approaches for individual and small-group prevention programs,(24, 90-92) there has been little-to-none on eHealth HIV prevention. $(30,31,93,94)$ The proposed study will lead the way in understanding the implementation of eHealth HIV prevention interventions to ensure the promise of cost-effective scalability is realized.(95)

\section{Abbreviations}




\begin{tabular}{|ll|}
\hline Term & Acronym \\
\hline Centers for Disease Control and Prevention & CDC \\
\hline Cluster-Randomized Trial & CRT \\
\hline Community-Based Organization & CBO \\
\hline Condomless Anal Sex & CAS \\
\hline Consolidated Framework for Implementation Research & CFIR \\
\hline Direct-to-Consumer & DTC \\
\hline Evidence-Based Intervention & EBI \\
\hline Food and Drug Administration & FDA \\
\hline Human Immunodeficiency Virus & HIV \\
\hline Keep It Up! & KIU \\
\hline Male Assigned At Birth & MAAB \\
\hline Men Who Have Sex With Men & MSM \\
\hline Multivariable Generalized Linear Mixed Models & GLMM \\
\hline National Institutes of Health & NIH \\
\hline Pre-Exposure Prophylaxis & PrEP \\
\hline Public Health Impact & PHI \\
\hline Randomized-Controlled Trials & RCTs \\
\hline Request for Proposals & RFP \\
\hline Research Electronic Data Capture & REDCap \\
\hline Sexually Transmitted Infection & STI \\
\hline Short Message Service & SMS \\
\hline U.S. Food and Drug Administration & FDA \\
\hline Young Men Who Have Sex With Men & YMSM \\
\hline
\end{tabular}

\section{Declarations}

\section{Ethics Approval and Consent to Participate}

This protocol was approved by the IRB at Northwestern University, IRB reference number STU00207476. The protocol is currently on version 1.9. YMSM and CBO staff participants will be informed of the aims of the study as well as data protection; all participants will be consented to participate in our trial. Reports derived from our trial will be delivered in aggregate such that participants cannot be identified. 


\section{Consent for Publication}

Not applicable.

\section{Availability of Data and Materials}

The datasets generated and/or analyzed during this trial will be available from the investigators upon reasonable request.

\section{Competing Interests}

The authors declare that they have no competing interests.

\section{Funding}

Research reported in this publication was supported by the National Institute of Mental Health, National Institute on Drug Abuse, and Office of the Director of the National Institutes of Health under Award Number $\mathrm{R} 01 \mathrm{MH} 118213$. The content is solely the responsibility of the authors and does not necessarily represent the official views of the National Institutes of Health.

\section{Authors' Contributions}

$\mathrm{BM}$ is the principal investigator of the trial, and led the design of the study, the research team, and data collection; he participated in the writing and editing of the manuscript. JPJ wrote the abstract and sections on the county selection and RFP processes, CBO study status, and discussion; he also acted as project lead in constructing the manuscript and provided substantial editorial support across all sections. NB provided content and editorial support for the RFP process and CBO study status and contributed to the design of the study. KM and KLM co-wrote all DTC sections; KM contributed to the design of the study. GS and EB co-wrote the sections on participant inclusion criteria, measures, and data analysis as well as constructed measures tables. BRS and AS contributed content and editorial support to the data analysis and measures tables; BRS contributed to the design of the study. DHL and RS co-wrote the sections on the KIU intervention background and intervention delivery. JDS and CHB contributed to the design of the study and provided editorial support for the data analysis and measures sections of the manuscript. AD wrote the section on CBO training. BPL and PJ contributed to the design of the study. All authors read and approved the final manuscript.

\section{Acknowledgments}

We would like to thank the staff of the $22 \mathrm{CBO}$ s at which $\mathrm{KIU}$ is being implemented as well as the many community partners who are assisting in recruitment for the DTC arm. Additionally, we thank the following centers and institutions for their immeasurable contributions to our trial: Center for Prevention Implementation Methodology for Drug Abuse and HIV; Prevention Science and Methodology Group; Third Coast Center for AIDS Research; Center for Behavioral Intervention Technologies; the Institute for Sexual and Gender Minority Health and Wellbeing, Feinberg School of Medicine, and the Department of Medical Social Sciences at Northwestern University; Center for Health Economics of Treatment Interventions for Substance Abuse 
Disorders, HCV, and HIV; Department of Healthcare Policy and Research at Weill Cornell Medical College; Boston Medical Center; and Erik Munson of Clinical Laboratory Science at Marquette University.

\section{References}

1. Centers for Disease Control and Prevention. HIV Surveillance Report, 2018 (Updated). 2020.

2. Centers for Disease Control and Prevention. HIV Infection Risk, Prevention, and Testing Behaviors among Men Who Have Sex with Men - National HIV Behavioral Surveillance, 23 U.S. Cities, 2017 Atlanta, GA2019 [updated February 2019. Available from: https://www.cdc.gov/hiv/library/reports/hiv-surveillance.html.

3. Crepaz N, Marks G, Mansergh G, Murphy S, Miller LC, Appleby PR. Age-related risk for HIV infection in men who have sex with men: examination of behavioral, relationship, and serostatus variables. AIDS Educ Prev. 2000;12(5):405-15.

4. Garofalo R, Hotton AL, Kuhns LM, Gratzer B, Mustanski B. Incidence of HIV infection and sexually transmitted infections and related risk factors among very young men who have sex with men. J Acquir Immune Defic Syndr. 2016;72(1):79-86.

5. Halkitis P, Kapadia F, Ompad D. Incidence of HIV infection in young gay, bisexual, and other YMSM: The P18 cohort study. J Acquir Immune Defic Syndr. 2015;69(4):466-73.

6. CDC. Compendium of evidence-based interventions and best practices for HIV prevention 2017 [Available from: http://www.cdc.gov/hiv/prevention/research/compendium/rr/complete.html.

7. Sullivan PS, Peterson J, Rosenberg ES, Kelley CF, Cooper H, Vaughan A, et al. Understanding racial HIV/STI disparities in black and white men who have sex with men: a multilevel approach. PloS one. 2014;9(3):e90514.

8. Steele BC, Melendez-Morales L, Campoluci R, DeLuca N, Dean HD. Health disparities in HIV/AIDS, viral hepatitis, sexually transmitted dieseases, and Turberculosis: Issues, burden, and response, a retrospective review 2000-2004. Atlanta: Center for Disease Control and Prevention; 2007.

9. CDC. Sexually transmitted disease surveillance 2015. Atlanta: US Deptartment of Health and Human Services; 2016.

10. Kelley CF, Vaughan AS, Luisi N, Sanchez TH, Salazar LF, Frew PM, et al. The effect of high rates of bacterial sexually transmitted infections on HIV incidence in a cohort of Black and White men who have sex with men in Atlanta, Georgia. AIDS Res Hum Retroviruses. 2015;31(6):587-92.

11. Bernstein KT, Marcus JL, Nieri G, Philip SS, Klausner JD. Rectal gonorrhea and chlamydia reinfection is associated with increased risk of HIV seroconversion. J Acquir Immune Defic Syndr. 2010;53(4):537-43.

12. Barbee LA, Khosropour CM, Dombrowksi JC, Golden MR. New human immunodeficiency virus diagnosis independently associated with rectal gonorrhea and chlamydia in men who have sex with men. Sexually transmitted diseases. 2017;44(7):385-9.

13. CDC. HIV risk and prevention estimates Atlanta, GA: Division of HIV/AIDS Prevention; National Center for HIV/AIDS, Viral Hepatitis, STD, and TB Prevention; Centers for Disease Control and Prevention; 2017 [Available from: https://www.cdc.gov/hiv/risk/estimates/index.html.

14. Mustanski B, Fisher CB. HIV rates are increasing in gay/bisexual teens: IRB barriers to research must be resolved to bend the curve. Am J Prev Med. 2016;51(2):249-52. 
15. Bell SG, Newcomer SF, Bachrach C, Borawski E, Jemmott JB, 3rd, Morrison D, et al. Challenges in replicating interventions. J Adolesc Health. 2007;40(6):514-20.

16. Neumann MS, Sogolow ED. Replicating effective programs: HIV/AIDS prevention technology transfer. AIDS Educ Prev. 2000;12(5 Suppl):35-48.

17. Swendeman D, Rotheram-Borus MJ. Innovation in sexually transmitted disease and HIV prevention: internet and mobile phone delivery vehicles for global diffusion. Curr Opin Psychiatry. 2010;23(2):139-44.

18. Kelly JA, Spielberg F, McAuliffe TL. Defining, designing, implementing, and evaluating phase 4 HIV prevention effectiveness trials for vulnerable populations. J Acquir Immune Defic Syndr. 2008;47 Suppl 1:S28-33.

19. Rietmeijer CA. Risk reduction counselling for prevention of sexually transmitted infections: how it works and how to make it work. Sex Transm Infect. 2007;83(1):2-9.

20. Solomon J, Card JJ, Malow RM. Adapting efficacious interventions: Advancing translational research in HIV prevention. Eval Health Prof. 2006;29(2):162-94.

21. CDC. High-impact HIV prevention: CDC's approach to reducing HIV infections in the United States. Centers for Disease Control and Prevention; National Center for HIV/AIDS, Viral Hepatitis, STD, and TB Prevention; Division of HIV/AIDS Prevention; 2011.

22. Kegeles SM, Hays RB, Coates TJ. The Mpowerment Project: A community-level HIV prevention intervention for young gay men. Am J Public Health. 1996;86(8):1129-36.

23. Jones KT, Gray P, Whiteside YO, Wang T, Bost D, Dunbar E, et al. Evaluation of an HIV prevention intervention adapted for Black men who have sex with men. Am J Public Health. 2008;98(6):1043-50.

24. Kegeles SM, Rebchook G, Tebbetts S, Arnold E, Team T. Facilitators and barriers to effective scale-up of an evidence-based multilevel HIV prevention intervention. Implement Sci. 2015;10:50.

25. Glasgow RE, Eckstein ET, Elzarrad MK. Implementation science perspectives and opportunities for HIV/AIDS research: Integrating science, practice, and policy. J Acquir Immune Defic Syndr. 2013;63 Suppl 1:S26-31.

26. Lenhart A. Teen, social media and technology overview 2015. Pew Research Center; 2015.

27. Bowen AM, Horvath K, Williams ML. A randomized control trial of Internet-delivered HIV prevention targeting rural MSM. Health Educ Res. 2007;22(1):120-7.

28. Bowen A, Williams M, Daniel C, Clayton S. Internet based HIV prevention research targeting rural MSM: feasibility, acceptability, and preliminary efficacy. Journal of behavioral medicine. 2008;31(6):463-77.

29. Noar SM, Pierce LB, Black HG. Can computer-mediated interventions change theoretical mediators of safer sex? A meta-analysis. Human Communication Research. 2010;36(3):261-97.

30. Bailey J, Mann S, Wayal S, Hunter R, Free C, Abraham C, et al. Sexual health promotion for young people delivered via digital media: A scoping review. Public Health Research. 2015;3(13).

31. Noar SM. Computer technology-based interventions in HIV prevention: state of the evidence and future directions for research. AIDS Care. 2011;23(5):525-33.

32. Hassan A, Scherer EA, Pikcilingis A, Krull E, McNickles L, Marmon G, et al. Improving Social Determinants of Health: Effectiveness of a Web-Based Intervention. Am J Prev Med. 2015;49(6):822-31. 
33. Bauermeister JA, Pingel ES, Jadwin-Cakmak L, Harper GW, Horvath K, Weiss G, et al. Acceptability and preliminary efficacy of a tailored online HIV/STI testing intervention for young men who have sex with men: the Get Connected! program. AIDS Behav. 2015;19(10):1860-74.

34. Greene GJ, Madkins K, Andrews K, Dispenza J, Mustanski B. Implementation and evaluation of the Keep It Up! online HIV prevention intervention in a community-based setting. AIDS Educ Prev. 2016;28(3):23145.

35. Madkins K, Moskowitz DA, Moran K, Dellucci T, Mustanski B. Measuring acceptability and engagement of the Keep It Up! internet-based HIV prevention randomized controlled trial for young men who have sex with men. AIDS Educ Prev. 2019;31(4):287-305.

36. Mustanski B, Garofalo R, Monahan C, Gratzer B, Andrews R. Feasibility, acceptability, and preliminary efficacy of an online HIV prevention program for diverse young men who have sex with men: The Keep It Up! intervention. AIDS and Behavior. 2013;17(9):2999-3012.

37. Mustanski B, Madkins K, Greene GJ, Parsons JT, Johnson BA, Sullivan P, et al. Internet-based HIV prevention with at-home sexually transmitted infection testing for young men having sex with men: study protocol of a randomized controlled trial of Keep It Up! 2.0. JMIR Research Protocols. 2017;6(1):e1.

38. Mustanski B, Parsons JT, Sullivan PS, Madkins K, Rosenberg E, Swann G. Biomedical and behavioral outcomes of Keep It Up!: An eHealth HIV prevention program RCT. American Journal of Preventive Medicine. 2018;55(2):151-8.

39. Centers for Disease Control and Prevention. Compendium of evidence-based interventions and best practices for HIV prevention Atlanta, GA: Division of HIV/AIDS Prevention, National Center for HIV/AIDS, Viral Hepatitis, STD, and TB Prevention, Centers for Disease Control and Prevention; 2019 [Available from: https://www.cdc.gov/hiv/research/interventionresearch/compendium/index.html.

40. Aarons GA, Fettes DL, Sommerfeld DH, Palinkas LA. Mixed methods for implementation research: Application to evidence-based practice implementation and staff turnover in community-based organizations providing child welfare services. Child Maltreat. 2012;17(1):67-79.

41. Palinkas LA, Roades Cooper B. Mixed methods evaluation in dissemination and implementation science. In: Brownson RC, Colditz GA, Proctor EK, editors. Dissemination and implementation research in health. 2nd ed. New York, NY: Oxford University Press; 2017.

42. Palinkas LA, Cooper BR. Mixed Methods Evaluation in Dissemination and Implementation Science. Dissemination and Implementation Research in Health. 2 ed. New York: Oxford University Press; 2017.

43. Center for Health Economics of Treatment Interventions for Substance Use Disorders H, and HIV (CHERISH), Budget impact tool New York, NY: Weill Cornell Medicine, Boston Medical Center, University of Pennsylvania, and University of Miami; 2015 [Available from:

http://cherishresearch.org/resources/\#Budgetlmpact.

44. Palinkas LA, Spear SE, Mendon SJ, Villamar J, Valente T, Chou CP, et al. Measuring sustainment of prevention programs and initiatives: A study protocol. Implement Sci. 2016;11:95.

45. Grey JA, Bernstein KT, Sullivan PS, Purcell DW, Chesson HW, Gift TL, et al. Estimating the population sizes of men who have sex with men in US states and counties using data from the American Community Survey. JMIR Public Health Surveill. 2016;2(1):e14. 
46. Brown $\mathrm{CH}$, Liao J. Principles for designing randomized preventive trials in mental health: an emerging developmental epidemiology paradigm. Am J Community Psychol. 1999;27(5):673-710.

47. Glasgow RE, Vogt TM, Boles SM. Evaluating the public health impact of health promotion interventions: The RE-AIM framework. Am J Public Health. 1999;89(9):1322-7.

48. Kessler RS, Purcell EP, Glasgow RE, Klesges LM, Benkeser RM, Peek CJ. What does it mean to "employ" the RE-AIM model? Eval Health Prof. 2013;36(1):44-66.

49. Abrams DB, Orleans CT, Niaura RS, Goldstein MG, Prochaska JO, Velicer W. Integrating individual and public health perspectives for treatment of tobacco dependence under managed health care: A combined stepped-care and matching model. Ann Behav Med. 1996;18(4):290-304.

50. Glasgow RE, Klesges LM, Dzewaltowski DA, Estabrooks PA, Vogt TM. Evaluating the impact of health promotion programs: using the RE-AIM framework to form summary measures for decision making involving complex issues. Health Education Research. 2006;21(5):688-94.

51. Damschroder LJ, Aron DC, Keith RE, Kirsh SR, Alexander JA, Lowery JC. Fostering implementation of health services research findings into practice: A consolidated framework for advancing implementation science. Implement Sci. 2009;4:50.

52. Drummond MF, Schulpher MJ, Claxton K, Stoddart GL, Torrance GW. Methods for the economic evaluation of health care programmes. Fourth ed. Oxford University Press2015.

53. Glick HA, Doshi JA, Sonnad SS, Polsky D. Economic evaluation in clinical trials: Oxford University Press; 2014.

54. CDC Division of HIV/AIDS Prevention. Turning the tide on HIV: Division of HIV/AIDS Prevention Annual Report 2013. Atlanta, GA: Centers for Disease Control and Prevention; 2013.

55. Purcell D. CDC's approach to high-impact HIV prevention in the era of expanding prevention options. 23rd Annual Illinois State HIV/STD Conference; Springfield, IL2014.

56. Grant RM, Lama JR, Anderson PL, McMahan V, Liu AY, Vargas L, et al. Preexposure chemoprophylaxis for HIV prevention in men who have sex with men. The New England journal of medicine. 2010;363(27):2587-99.

57. Hughes JP, Baeten JM, Lingappa JR, Magaret AS, Wald A, de Bruyn G, et al. Determinants of per-coital-act HIV-1 infectivity among African HIV-1-serodiscordant couples. J Infect Dis. 2012;205(3):358-65.

58. Smith DK, Herbst JH, Zhang X, Rose CE. Condom effectiveness for HIV prevention by consistency of use among men who have sex with men in the United States. J Acquir Immune Defic Syndr. 2015;68(3):33744.

59. Goodreau SM, Rosenberg ES, Jenness SM, Luisi N, Stansfield SE, Millett GA, et al. Sources of racial disparities in HIV prevalence in men who have sex with men in Atlanta, GA, USA: A modelling study. Lancet HIV. 2017;4(7):E311-E20.

60. Hedeker D, Gibbons RD, Flay BR. Random-effects regression models for clustered data with an example from smoking prevention research. Journal of Consulting and Clinical Psychology. 1994;62(4):757-65.

61. Fiero MH, Huang, S., Oren, E., \& Bell, M. L. Statistical analysis and handling of missing data in cluster randomized trials: a systematic review. Trials. 2016;17(1). 
62. Ten Have TR, Normand SL, Marcus SM, Brown CH, Lavori P, Duan N. Intent-to-treat vs. non-intent-to-treat analyses under treatment non-adherence in mental health randomized trials. Psychiatr Ann. 2008;38(12):772-83.

63. Brown CH, Wang W, Kellam SG, Muthen BO, Petras H, Toyinbo P, et al. Methods for testing theory and evaluating impact in randomized field trials: Intent-to-treat analyses for integrating the perspectives of person, place, and time. Drug Alcohol Depend. 2008;95 Suppl 1:S74-S104.

64. Neumann PJ, Sanders GD, Russell LB, Siegel JE, Ganiats TG. Cost-effectiveness in health and medicine. 2nd ed. New York, NY: Oxford University Press; 2017.

65. Graham JW. Missing data analysis: Making it work in the real world. Annu Rev Psychol. 2009;60:549-76.

66. Hollis S, Campbell F. What is meant by intention to treat analysis? Survey of published randomised controlled trials. BMJ. 1999;319(7211):670-4.

67. White IR, Horton NJ, Carpenter J, Pocock SJ. Strategy for intention to treat analysis in randomised trials with missing outcome data. BMJ. 2011;342:d40.

68. National Institutes of Health. Research methods resource: Group- or cluster-randomized trials (GRTs) Bethesda, MD: National Institutes of Health; 2017 [Available from:

https://researchmethodsresources.nih.gov/grt.aspx.

69. Vermund SH, Fidler SJ, Ayles H, Beyers N, Hayes RJ. Can combination prevention strategies reduce HIV transmission in generalized epidemic settings in Africa? The HPTN 071 (PopART) study plan in South Africa and Zambia. J Acquir Immune Defic Syndr. 2013;63 Suppl 2:S221-7.

70. Coates TJ, Kulich M, Celentano DD, Zelaya CE, Chariyalertsak S, Chingono A, et al. Effect of communitybased voluntary counselling and testing on HIV incidence and social and behavioural outcomes (NIMH Project Accept; HPTN 043): A cluster-randomised trial. Lancet Glob Health. 2014;2(5):e267-77.

71. Glassman JR, Potter SC, Baumler ER, Coyle KK. Estimates of intraclass correlation coefficients from longitudinal group-randomized trials of adolescent HIV/STI/pregnancy prevention programs. Health Educ Behav. 2015;42(4):545-53.

72. Witte SS, Wu E, El-Bassel N, Hunt T, Gilbert L, Medina KP, et al. Implementation of a couple-based HIV prevention program: A cluster randomized trial comparing manual versus Web-based approaches. Implement Sci. 2014;9:116.

73. National Center for HIV/AIDS VH, Sexually Transmitted Disease, and Tuberculosis Prevention,. Comprehensive high-impact HIV prevention projects for community-based organizations: CDC-RFA-PS151502. Atlanta, GA: Centers for Disease Control and Prevention; 2014.

74. Golub SA, Gamarel KE. The impact of anticipated HIV stigma on delays in HIV testing behaviors: Findings from a community-based sample of men who have sex with men and transgender women in New York City. AIDS Patient Care STDS. 2013;27(11):621-7.

75. Schwarcz S, Richards TA, Frank H, Wenzel C, Hsu LC, Chin CS, et al. Identifying barriers to HIV testing: Personal and contextual factors associated with late HIV testing. AIDS Care. 2011;23(7):892-900.

76. Siedner MJ, Ng CK, Bassett IV, Katz IT, Bangsberg DR, Tsai AC. Trends in CD4 count at presentation to care and treatment initiation in sub-Saharan Africa, 2002-2013: A meta-analysis. Clin Infect Dis. 2015;60(7):1120-7. 
77. Conway DP, Holt M, Couldwell DL, Smith DE, Davies SC, McNulty A, et al. Barriers to HIV testing and characteristics associated with never testing among gay and bisexual men attending sexual health clinics in Sydney. Journal of the International AIDS Society. 2015;18(1):20221.

78. Deblonde J, De Koker P, Hamers FF, Fontaine J, Luchters S, Temmerman M. Barriers to HIV testing in Europe: A systematic review. Eur J Public Health. 2010;20(4):422-32.

79. Lippman SA, Moran L, Sevelius J, Castillo LS, Ventura A, Treves-Kagan S, et al. Acceptability and feasibility of HIV self-testing among transgender women in San Francisco: A mixed methods pilot study. AIDS Behav. 2016;20(4):928-38.

80. de la Fuente L, Rosales-Statkus ME, Hoyos J, Pulido J, Santos S, Bravo MJ, et al. Are participants in a street-based HIV testing program able to perform their own rapid test and interpret the results? PloS one. 2012;7(10):e46555.

81. Bustamante MJ, Konda KA, Joseph Davey D, Leon SR, Calvo GM, Salvatierra J, et al. HIV self-testing in Peru: Questionable availability, high acceptability but potential low linkage to care among men who have sex with men and transgender women. Int J STD AIDS. 2017;28(2):133-7.

82. Tao J, Li MY, Qian HZ, Wang LJ, Zhang Z, Ding HF, et al. Home-based HIV testing for men who have sex with men in China: A novel community-based partnership to complement government programs. PloS one. 2014;9(7):e102812.

83. Krause J, Subklew-Sehume F, Kenyon C, Colebunders R. Acceptability of HIV self-testing: A systematic literature review. BMC Public Health. 2013;13:735.

84. Figueroa C, Johnson C, Verster A, Baggaley R. Attitudes and acceptability on HIV self-testing among key populations: A literature review. AIDS Behav. 2015;19(11):1949-65.

85. Witzel TC, Rodger AJ, Burns FM, Rhodes T, Weatherburn P. HIV self-testing among men who have sex with men (MSM) in the UK: A qualitative study of barriers and facilitators, intervention preferences and perceived impacts. PloS one. 2016;11(9):e0162713.

86. Durlak JA, DuPre EP. Implementation matters: A review of research on the influence of implementation on program outcomes and the factors affecting implementation. Am J Community Psychol. 2008;41(34):327-50.

87. Baker TB, Gustafson DH, Shah D. How can research keep up with eHealth? Ten strategies for increasing the timeliness and usefulness of eHealth research. J Med Internet Res. 2014;16(2):e36.

88. Murray E, Burns J, May C, Finch T, O'Donnell C, Wallace P, et al. Why is it difficult to implement e-health initiatives? A qualitative study. Implement Sci. 2011;6:6.

89. McCray E. Envisioning a bolder agenda for implementation science to improve HIV prevention and care outcomes. National CFAR Scientific Symposium; Washington, DC2017.

90. Rietmeijer CA, Bull SS, McFarlane M, Patnaik JL, Douglas JM, Jr. Risks and benefits of the internet for populations at risk for sexually transmitted infections (STIs): Results of an STI clinic survey. Sexually transmitted diseases. 2003;30(1):15-9.

91. Wilson MG, Rourke SB, Lavis JN, Bacon J, Travers R. Community capacity to acquire, assess, adapt, and apply research evidence: A survey of Ontario's HIV/AIDS sector. Implement Sci. 2011;6:54. 
92. Leeman J, Calancie L, Hartman MA, Escoffery CT, Herrmann AK, Tague LE, et al. What strategies are used to build practitioners' capacity to implement community-based interventions and are they effective?: A systematic review. Implement Sci. 2015;10:80.

93. Muessig KE, Nekkanti M, Bauermeister J, Bull S, Hightow-Weidman LB. A systematic review of recent smartphone, Internet and Web 2.0 interventions to address the HIV continuum of care. Current HIV/AIDS reports. 2015;12(1):173-90.

94. Guse K, Levine D, Martins S, Lira A, Gaarde J, Westmorland W, et al. Interventions using new digital media to improve adolescent sexual health: a systematic review. Journal of Adolescent Health. 2012;51(6):53543.

95. Bauer MS, Damschroder L, Hagedorn H, Smith J, Kilbourne AM. An introduction to implementation science for the non-specialist. BMC Psychol. 2015;3:32.

\section{Figures}

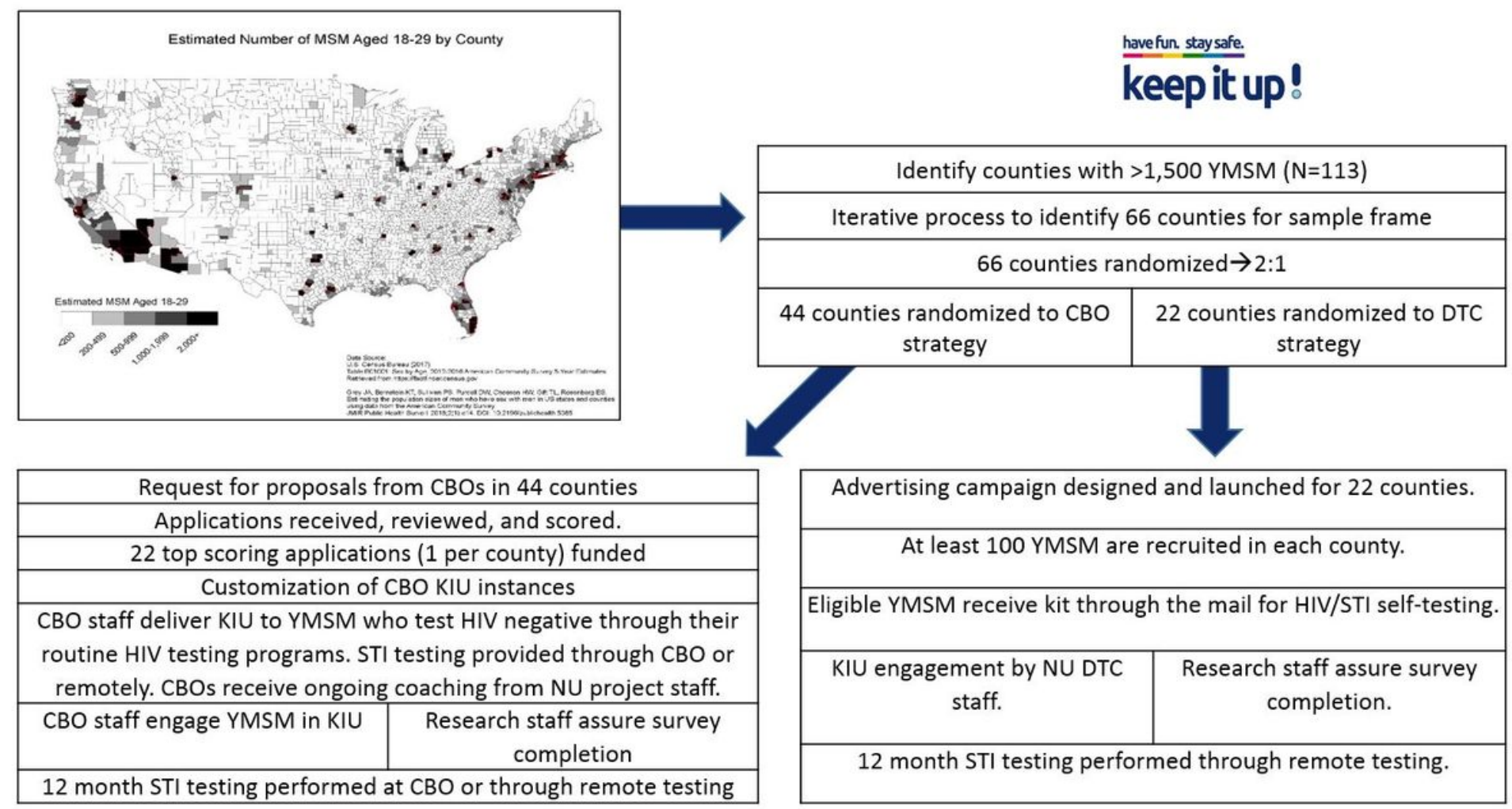

\section{Figure 1}

KIU! 3.0 Trial Design illustrates our primary design elements. 


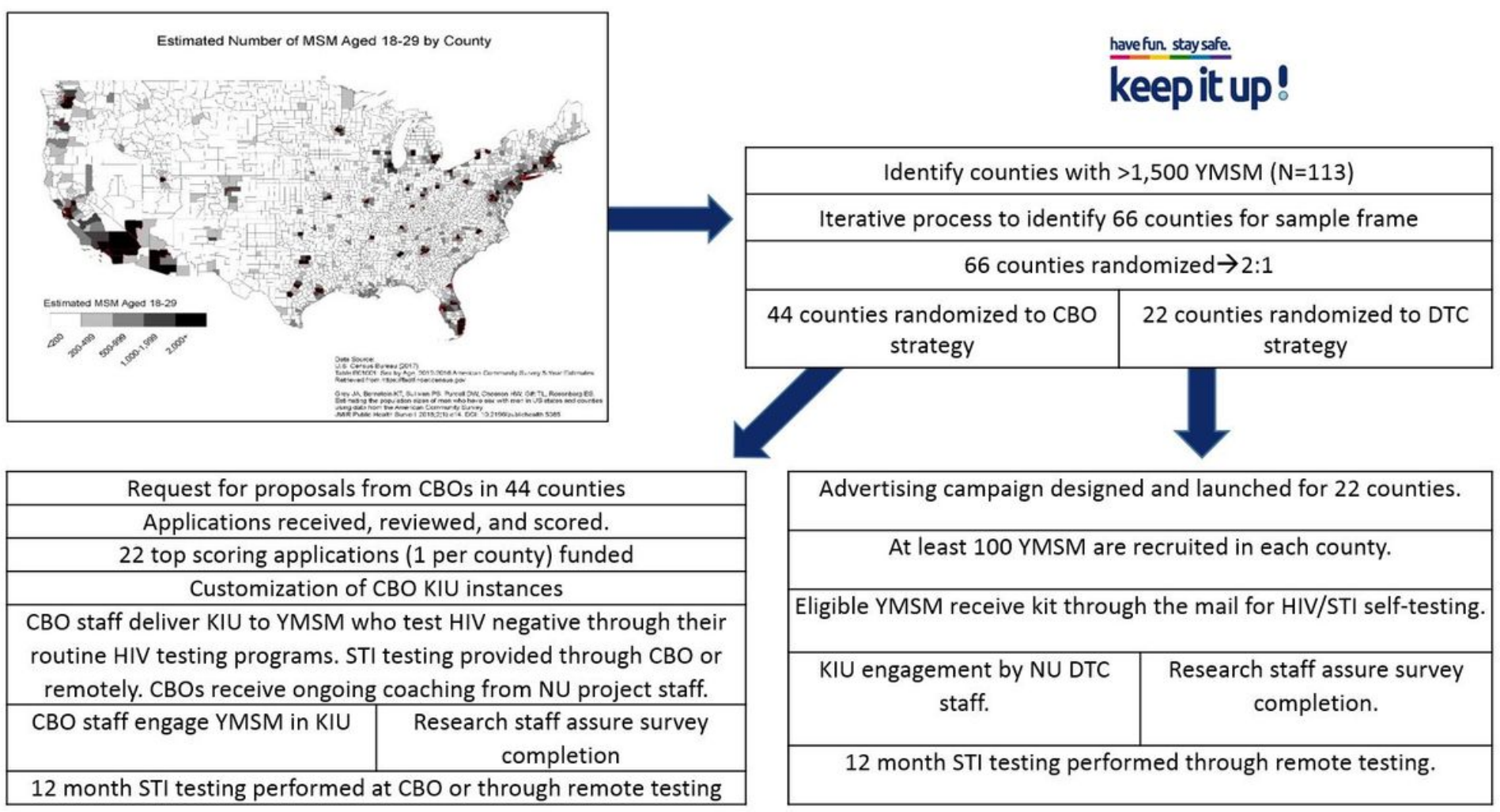

\section{Figure 1}

KIU! 3.0 Trial Design illustrates our primary design elements. 


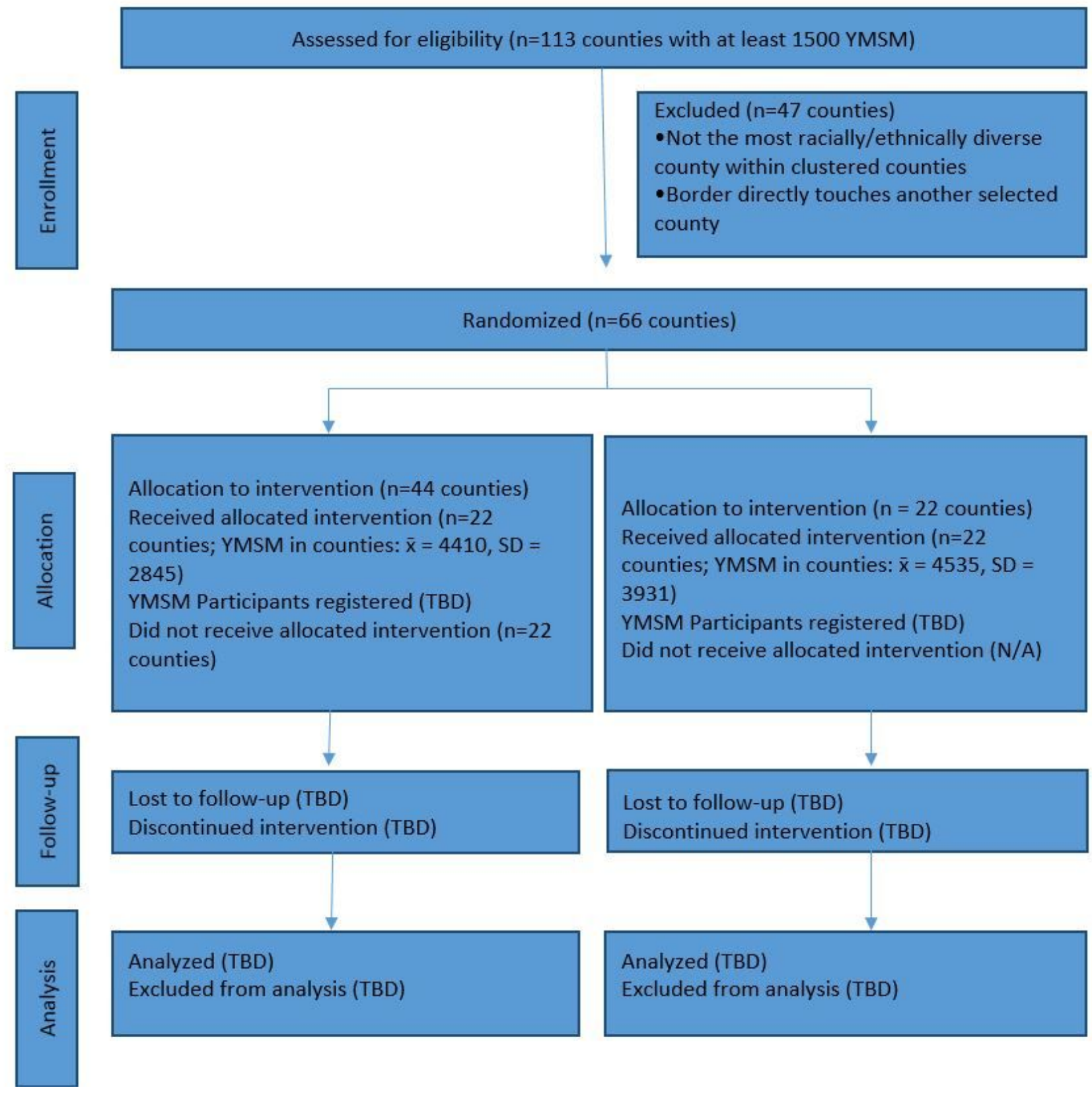

Figure 2

CONSORT diagram of the flow of the trial 


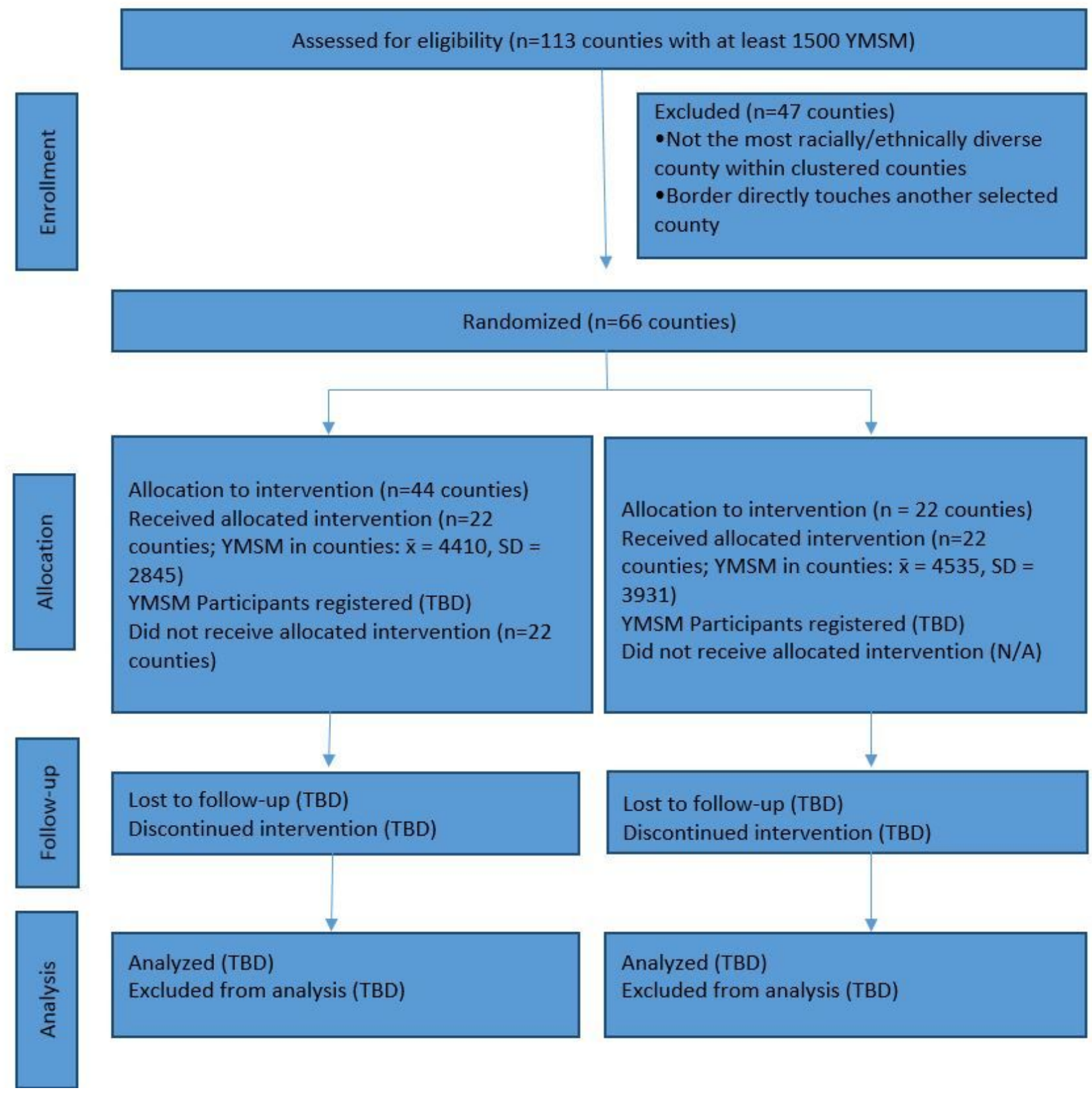

Figure 2

CONSORT diagram of the flow of the trial

\section{Supplementary Files}

This is a list of supplementary files associated with this preprint. Click to download.

- AdditionalFile1Supplementallnformationtablemoved.docx

- AdditionalFile1Supplementallnformationtablemoved.docx

- KIU3.0Protocolv.1.98September2020clean.docx

- KIU3.0Protocolv.1.98September2020clean.docx 
- KIUProtocolPaperCONSORTChecklist.docx

- KIUProtocolPaperCONSORTChecklist.docx 